\title{
Genetic differentiation through dispersal and isolation in two freshwater fish species from coastal basins of a Northeastern Brazil
}

Correspondence:

João Marcelo S. Abreu joaabreu@hotmail.com

Submitted February 25, 2019

Accepted July 22, 2020

by Priscila Camelier

Epub October 09, 2020

\author{
${ }^{\oplus}$ João Marcelo S. Abreu ${ }^{1},{ }^{\oplus}$ Brandon T. Waltz ${ }^{2}$, James S. Albert ${ }^{2}$ and \\ ${ }^{\oplus}$ Nivaldo M. Piorski ${ }^{3}$
}

The coastal basins in Northeastern Brazil used in this study make up two different ecoregions for freshwater fishes (Amazonas estuary and coastal drainages, and Parnaiba) and two areas of endemism for Characiformes (Maranhão and Parnaíba), and exhibits a diversified yet poorly explored freshwater fish fauna. The population structure and biogeography of two migratory freshwater fish species that are commercially exploited from Maranhão and Parnaíba regions were herein analyzed. Molecular sequence data and statistical analyses were used to estimate haplotypes networks and lineage divergence times and correlated with hydrographic history of drainage and paleodrainages of the region. A total of 171 sequences was produced for both species, Schizodon dissimilis $($ col, $\mathrm{n}=70)$ and Prochilodus lacustris (D-loop, $\mathrm{n}=101$ ). All analyses identified the presence of three genetically delimited groups of $S$. dissimilis and six groups of P. lacustris. The lineage time analyses indicate diversification among these species within the past 1 million year. The results indicate the influence of geodispersal in the formation of the ichthyofauna in the studied area through headwater stream capture events and reticulated connections between the mouths of rivers along the coastal plain due to eustatic sea level fluctuations.

Keywords: Characiformes, Headwater capture, Paleodrainages, Phylogeography, Sea-level change.
Online version ISSN 1982-0224 Print version ISSN 1679-6225

Neotrop. Ichthyol. vol. 18, no. 3, Maringá 2020
1 Programa de Pós-graduação em Biodiversidade e Biotecnologia (BIONORTE), Universidade Federal do Maranhão, 65080-805 São Luís, MA, Brazil. (JMSA) joaabreu@hotmail.com (corresponding author).

2 Department of Biology, University of Louisiana at Lafayette, 300 E St. Mary Blvd, 70504 Lafayette, LA, USA. (BTW) waltzbrandont@gmail.com; (JSA) jalbert@louisiana.edu.

3 Departamento de Biologia, Universidade Federal do Maranhão, 650080-805 São Luís, MA, Brazil. (NMP) nm.piorski@ufma.br. 
As bacias costeiras do nordeste do Brasil usadas neste estudo compõem duas ecorregiões diferentes para peixes de água doce (Estuário do Amazonas e drenagens costeiras e Parnaíba) e duas áreas de endemismo para Characiformes (Maranhão e Parnaíba), exibindo uma diversificada e ainda pouco explorada fauna de peixes de água doce. A estrutura populacional e biogeografia de duas espécies migradoras de peixes de água doce exploradas comercialmente nas regiões do Maranhão e Parnaíba foram analisadas. Dados de sequências moleculares e análises estatísticas foram utilizados para estimar redes de haplótipos e tempos de divergência entre linhagens, e foram correlacionados com a história hidrográfica das drenagens e paleodrenagens da região. Um total de 171 sequências foram geradas para ambas espécies, Schizodon dissimilis (coI, $\mathrm{n}=70$ ) e Prochilodus lacustris (D-loop, $\mathrm{n}=101$ ). Todas análises identificaram a presença de três grupos geneticamente delimitados para $S$. dissimilis e seis grupos para $P$. lacustris. A análise de tempo de divergência das linhagens indicou uma diversificação entre estas espécies nos últimos $1 \mathrm{Ma}$. Os resultados indicam influência da geodispersão na formação da ictiofauna do Maranhão, devido eventos de capturas de cabeceira e conexões reticuladas entre as fozes dos rios ao longo da planície costeira devido às flutuações eustáticas do nível do mar.

Palavras-chave: Captura de cabeceira, Characiformes, Filogeografia, Mudanças no nível do mar, Paleodrenagens.

\section{INTRODUCTION}

Studies using phylogenetic and comparative approaches to understand the biodiversity and biogeography of South American fishes are many and varied (e.g. Sivasundar et al., 2001; Beheregaray et al., 2002; Farias, Hrbek, 2008; Albert et al., 2011a; Pereira et al., 2013). Most of these studies focus on hypotheses to explain the origin, richness, and distribution patterns of fishes in fauna of the Amazon and adjacent river basins of northern South America. Some of these hypotheses, such as refuges, museums, and paleogeographic events (Endler, 1982; Fjeldså, 1994; Roy et al., 1997; Montoya-Burgos, 2003; Hubert, Renno, 2006; Haffer, 2008), were derived from studies of diversification in terrestrial taxa and adapted to fit certain groups of freshwater organisms.

River capture and sea-level changes are geomorphological and climatic processes that strongly constrain the biological processes of dispersal and gene flow in obligate freshwater taxa (Albert et al., 2011b; Dias et al., 2014; Thomaz et al., 2015, 2017; Albert et al., 2018; Thomaz, Knowles, 2018). By altering hydrographic connections among portions of river drainage networks, these processes act to separate and merge adjacent river segments, thereby promoting both speciation and extinction, and increasing the rate of net lineage diversification (Fagan, 2002; Albert, Crampton, 2010; Albert et al., 2016). The combined action of these processes results in a history of landscape evolution events that may be modelled as alternative paleogeographic hypotheses (Albert et al., 2011a; Thomaz et al., 2015).

Paleogeographic hypotheses regarding changing connections among rivers of 
northern South America have considered the role of semipermeable watershed barriers and the uplift or burial of structural arches that bound major sedimentary basins (Albert et al., 2006; Winemiller et al., 2008; Lovejoy et al., 2010; Albert et al., 2018). Hydrogeologic hypotheses consider the role of headwater and lateral river capture events as geodispersal events, which move the location of barriers among the basins and promote the colonization of new areas, followed by differentiation (Hubert, Renno, 2006). The coastal dispersion or paleodrainage dispersal hypothesis posits the effects of sea-level fluctuations on changing shorelines and patterns of river-mouth connectivity through time (Huber, 1998; Thomaz, Knowles, 2018). These distinct events can influence the process of population differentiation and/or speciation acting both between (river capture) and within (river capture and sea level change) basins.

The Maranhão region of Northeastern Brazil exhibits a diverse and poorly explored freshwater fish fauna and is represented in different configurations in studies based in the distribution patterns of the species. This area has been treated as representing two different ecoregions (Abell et al., 2008; the Amazonas estuary and coastal drainages, and Parnaiba), and alternatively two distinct areas of endemism (to Hubert, Renno, 2006; Maranhão and Parnaíba), differentiated by the size of the areas. In recent years, the description of new species (e.g. Piorski et al., 2008; Ottoni, 2011; Ramos et al., 2017; Guimarães et al., 2018a,b; Rocha et al., 2018; Zanata et al., 2018) and the compilation of taxonomic distributions (e.g. Melo et al., 2016; Abreu et al., 2019) for this area have improved the knowledge about the ichthyofauna diversity, and opened new questions regarding the processes involved in the evolution of fish groups of this region. The five principal river drainages of the study area are the Parnaíba, Itapecuru, Mearim, Turiaçu and Gurupi basins. To date, information about fish diversity has been published only for the first four of these basins (e.g. Piorski et al., 1998, 2003, 2007; Soares, 2005; Barros et al., 2011; Ramos et al., 2014).

Several papers have proposed dispersal along the coastal plain to explain diversity patterns among fishes shared by the Amazonian and these drainages (e.g. Huber, 1998; Montoya-Burgos, 2003; Hubert, Renno, 2006). According to this model, dispersal, speciation and extinction were promoted by sea-level changes through the Neogene $(20.4-2.6 \mathrm{Ma})$ and Quaternary $(2.6-0.01 \mathrm{Ma})$. During episodes of marine regressions and transgressions, mouths of coastal rivers became connected and disconnected, respectively, resulting in episodes in which populations of adjacent basins were merged and isolated (Hanebuth et al., 2011; Roxo et al., 2014). The ichthyofauna of the Amazon and these coastal basins is also thought to have been affected by the Neogene uplift of the Serra do Tiracambu mountain range (Piorski, 2010). Beginning in the Late Miocene, the Tiracambu range arose to form the watershed divides between the Tocantins basin draining its western slope, and the coastal Gurupi and Mearim basins that drain its north and northeastern slopes (Soares Júnior et al., 2011). The approximate timing of this geological event generally coincides with estimated lineages divergence times for Hypostomus Lacepède, 1803, species that inhabit these three basins (Montoya-Burgos, 2003).

The population and biogeographic structure of two characiform freshwater fish species, Schizodon dissimilis (Garman, 1890) (Anostomidae) and Prochilodus lacustris Steindachner, 1907 (Prochilodontidae) (Fig. 1) is herein conducted, from the Maranhão and Parnaíba regions of northeastern Brazil. According the original description (Garman, 
1890) and the Eschmeyer's Catalog of Fishes (Fricke et al., 2020), Schizodon dissimilis is distributed only in the Poti River of the Parnaíba basin and, according to Barros et al. (2011), in the Itapecuru basin. Abreu (2013) expanded the known distribution to other localities in the Parnaíba basin, and also to the Mearim and Turiaçu basins. Prochilodus lacustris is distributed to the Parnaíba, Itapecuru, Mearim, Turiaçu, and Tocantins basins (Piorski, 2010; Barros et al., 2011; Fricke et al., 2020). The study seeks to identify the main hydrographic and paleogeographic events (river capture and dispersal by paleodrainages) that influenced the geographic distributions and evolutionary histories of these fish lineages. Through the use of haplotypes network, lineage divergence times, and statistical analyses using molecular data, and by comparing these biological data with available geological information from the region, we identify the most important paleogeographic events that promoted the differentiation of these species.

\section{MATERIAL AND METHODS}

Sampling and DNA extraction. Seventy individuals of Schizodon dissimilis and 101 individuals of Prochilodus lacustris were sampled from 14 localities across the Maranhão coastal basins including the Parnaíba, Itapecuru, Mearim, Turiaçu, and Tocantins basins (Tab. 1). Tissue samples were taken from fins of sampled individuals, preserved

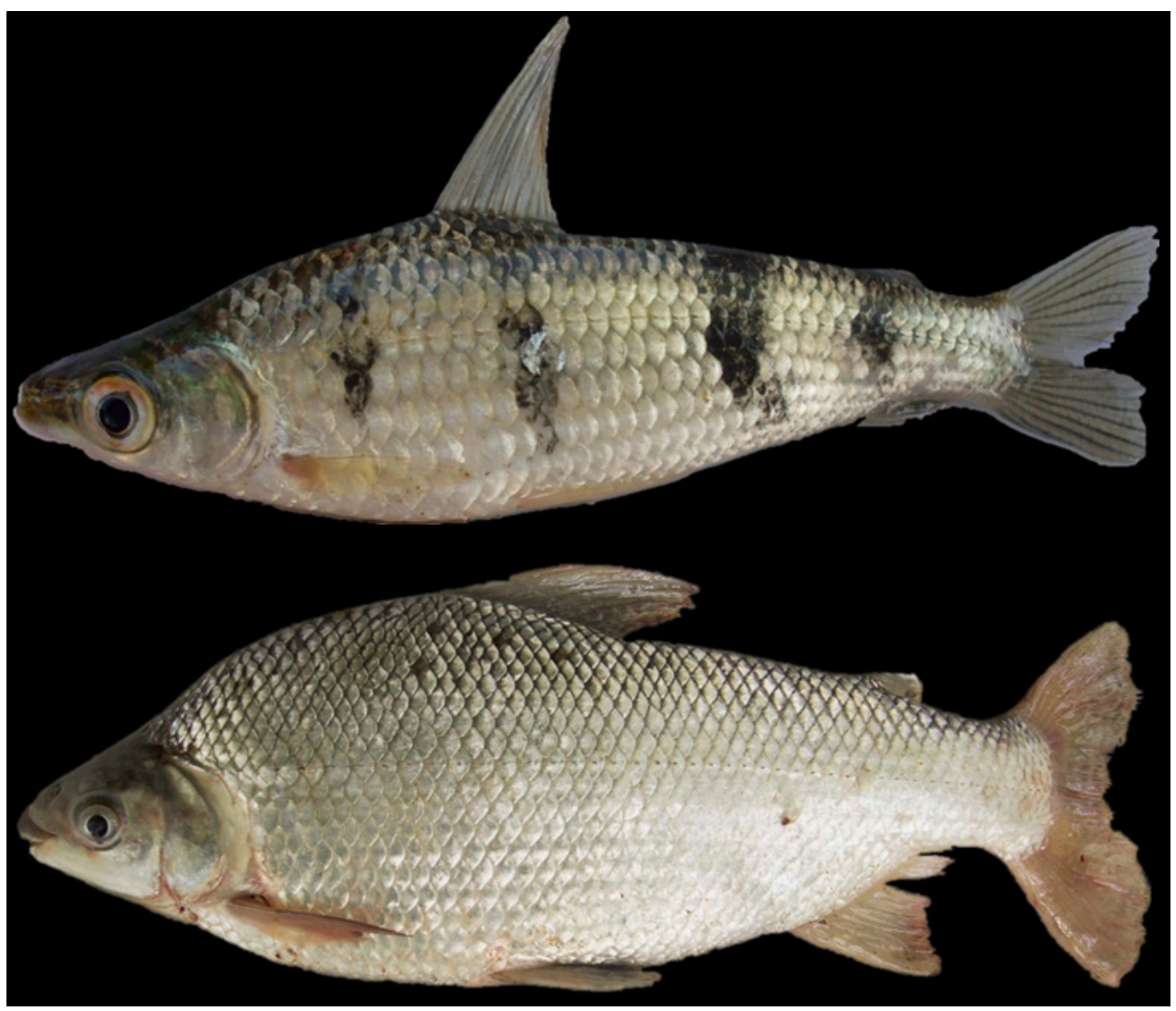

FIGURE 1 I Species used in this study, Schizodon dissimilis (above) and Prochilodus lacustris (below). 
in 99\% ethanol, and deposited in the "Coleção de Peixes da Universidade Federal do Maranhão" (CPUFMA). DNA was extracted from samples using the Wizard Genomic DNA Purification kit (Promega) following manufacturer's protocol.

Amplification and sequencing. The Cytochrome oxidase subunit I (coI) gene was amplified by polymerase chain reaction (PCR) for $S$. dissimilis samples using the primers FishF1 and FishR1 (Ward et al., 2005). The amplification reaction was performed in a total volume of $25 \mu \mathrm{L}$ comprising $14.3 \mu \mathrm{L}$ of $\mathrm{H}_{2} \mathrm{O}, 4 \mu \mathrm{L}$ of dNTP mix $(1.25 \mathrm{mM}), 2.5$ $\mu \mathrm{L}$ of buffer $(10 \mathrm{x}), 1 \mu \mathrm{L}$ of $\mathrm{MgCl}_{2}(25 \mathrm{mM}), 1 \mu \mathrm{L}$ of each primer $(10 \mu \mathrm{M}), 0.2 \mu \mathrm{L}$ of Taq polymerase $(5 \mathrm{U} / \mu \mathrm{L})$ and $1 \mu \mathrm{L}$ of diluted DNA. The amplification sequence consisted of a denaturation step of $3 \mathrm{~min}$ at $95{ }^{\circ} \mathrm{C}$, followed by 30 cycles of $30 \mathrm{sec}$ at $94{ }^{\circ} \mathrm{C}, 30$ sec at $58{ }^{\circ} \mathrm{C}$, and $30 \mathrm{sec}$ at $72{ }^{\circ} \mathrm{C}$, ending in an extension phase of $3 \mathrm{~min}$ at $72{ }^{\circ} \mathrm{C}$. The control region of mtDNA (D-loop) was amplified by PCR for P. lacustris samples, using the primers F-TTF (Sivasundar et al., 2001) and H16498 (Kocher et al., 1989). Amplification was performed in a total volume of $30 \mu \mathrm{L}$ comprising $19.7 \mu \mathrm{L}$ of $\mathrm{H}_{2} \mathrm{O}$, $3 \mu \mathrm{L}$ of dNTP mix (1.25 mM), $3 \mu \mathrm{L}$ of buffer (10x), $1.2 \mu \mathrm{L}$ of $\mathrm{MgCl}_{2}(50 \mathrm{mM}), 1.2 \mu \mathrm{L}$ of each primer $(10 \mu \mathrm{M}), 0.2 \mu \mathrm{L}$ of Taq polymerase $(5 \mathrm{U} / \mu \mathrm{L})$ and $0.5 \mu \mathrm{L}$ of diluted DNA. The amplification phase consisted of a denaturation of $2 \mathrm{~min}$ at $94{ }^{\circ} \mathrm{C}$, followed by 35 cycles of $15 \mathrm{sec}$ at $94{ }^{\circ} \mathrm{C}, 15 \mathrm{sec}$ at $51{ }^{\circ} \mathrm{C}$, and $30 \mathrm{sec}$ at $72{ }^{\circ} \mathrm{C}$, ending in an extension phase of 5 min at $72{ }^{\circ} \mathrm{C}$.

Amplification products were visualized in 1\% agarose gel electrophoresis and purified with Illustra GFX PCR DNA and Gel Purification Kit (GE Healthcare). Samples were sequenced using both forward and reverse primers and Big Dye Terminator kit 3.1 Cycle Sequencing kit (Thermo Fisher Scientific) in ABI 3730 DNA Analyzer (Thermo Fisher Scientific). The quality of sequences was inspected using BioEdit 7.0.5.3 (Hall, 1999) and aligned using ClustalW 2.0.3 (Larkin et al., 2007). All sequences are deposited

TABLE 1 I Sampling sites of Schizodon dissimilis and Prochilodus lacustris analyzed in this study. Numbers in species columns indicate number of sampled individuals.

\begin{tabular}{|r|c|c|c|}
\hline Locality & Basin & Schizodon dissimilis & Prochilodus lacustris \\
\hline São João dos Patos & Parnaíba & 8 & 12 \\
Nova Iorque & Parnaíba & 5 & 0 \\
Santa Quitéria & Parnaíba & 8 & 9 \\
Colinas & Itapecuru & 2 & 1 \\
Codó & Itapecuru & 8 & 12 \\
Rosário & Itapecuru & 3 & 8 \\
\hline Pindaré-Mirim & Mearim & 3 & 7 \\
Buriticupu & Mearim & 4 & 9 \\
Penalva & Mearim & 9 & 10 \\
Lago Açu & Mearim & 4 & 11 \\
Arari & Mearim & 9 & 5 \\
Turiaçu & Turiaçu & 7 & 0 \\
\hline Santa Helena & Turiaçu & 0 & 10 \\
\hline Tucuruí & Tocantins & 0 & 7 \\
\hline
\end{tabular}


in NCBI with the follow corresponding accession number: MK530951-MK531020 to S. dissimilis and MK531021-MK531121 to P. lacustris (S1).

Genetic diversity and structure. Haplotype and nucleotide diversity indices were obtained using Arlequin 3.5.1.3 (Excoffier, Lischer, 2010). Tajima's D values were also calculated for selective neutrality testing (Tajima, 1989) and Fs (Fu, 1997). A Spatial Analysis of Molecular Variation (SAMOVA) in the program SAMOVA 2.0 (Dupanloup et al., 2002) was used to assess population structure. The variance was partitioned for haplotypes within populations, among groups and among populations within groups. Potential populations were identified using BAPS 6 (Bayesian Group Analysis; Corander et al., 2013) and a haplotype network was constructed to identify the genetic distances among and within populations using the program Haploviewer 1.6 (Salzburger et al., 2011). In all analyses each basin was considered as a group and each locality as a population.

Phylogenetics analyses. The best molecular evolution model for the data was obtained using jModelTest 2 (Darriba et al., 2012). Bayesian Information Criterion (BIC) identified HKY $+\mathrm{I}$ as the best model for both genes coI and D-Loop. A molecular clock was applied to the tree through BEAST 2.4.7 program (Bouckaert et al., 2014), to identify divergence times among populations. The analysis was run with 200 million generations in 4 runs, sampled every 1,000 states with a burn-in of first $10 \%$ of the generations excluded. We used for both species the substitution rate of $1.67 \%$ of genetic divergence per million years proposed by Sivasundar et al. (2001). The maximum credibility tree was visualized with TreeAnnotator 1.8.1 after an additional burn-in period of 20,000. Median node ages and 95\% highest posterior density (HPD) intervals were plotted in the chronogram.

Reconstruction of paleodrainages. Paleodrainage boundaries at the Last Glacial Maximum (LGM) (e.g. Dias et al., 2014; Thomaz et al., 2015; Thomaz, Knowles, 2018) was estimated using topographical and bathymetric information extracted from a digital elevation model (DEM) GEBCO_2014 at 30 arc-second resolution (ca. $1 \mathrm{~km}$; http:// www.gebco.net/) (Weatherall et al., 2015) using hydrological and spatial tools available in the GRASS environment of QGIS 3.2.3 (QGIS Development Team, 2018). In QGIS program the areas were delimited using the Contour and Mask tools; elevation and flow directions were identified using the Fill and Carve tools; river basin boundaries using the Watershed tool; and sea channel boundaries using the Lake tool. These coastline models were used to identify the minimum and the maximum number of basins with a separate mouth to the sea during the estimated period and to infer whether this connection and separation processes influenced the distribution of the studied species, considering a sealevel of - $122 \mathrm{~m}$, previously proposed by Hansen et al. (2013).

Test of relationship between genetic diversity and geographical structure. An AMOVA test using Arlequin 3.5.1.3 (Excoffier, Lischer, 2010), was conducted to investigate if the found genetic diversity can be explained by one of the hydrological arrangement proposals for the region. We conduct four tests with different populations configurations (K): 1) ecoregion semipermeable barriers proposal by Abell et al. (2008) 
with $\mathrm{K}=2$ (Amazon estuary x Parnaíba); 2) areas of endemism proposal by Hubert, Renno (2006) with $\mathrm{K}=2$ for $S$. dissimilis (Maranhão x Parnaíba) and $\mathrm{K}=3$ for P. lacustris (Tocantins x Maranhão x Parnaíba); 3) paleodrainages, considering the simulation executed by us, with $\mathrm{K}=3$ for $S$. dissimilis and $\mathrm{K}=4$ for P. lacustris; and 4 ) using the current basins division were the samples were collected, with $\mathrm{K}=4$ for $S$. dissimilis (Parnaíba, Itapecuru, Mearim, and Turiaçu) and $\mathrm{K}=5$ for $P$. lacustris (Parnaíba, Itapecuru, Mearim, Turiaçu, and Tocantins). To estimate the genetic variability of the possible populations, the pairwise genetic differentiation indices (Fst), was estimated in the software Arlequin 3.5.1.3 (Excoffier, Lischer, 2010).

\section{RESULTS}

Phylogeographic analyses. A total of 171 sequences for both genes were produced: Schizodon dissimilis (coI, $\mathrm{n}=70,623 \mathrm{bp}, 12$ haplotypes) and P. lacustris (D-loop, $\mathrm{n}=$ 101, $702 \mathrm{bp}, 49$ haplotypes). The difference in haplotype numbers between the species is expected more due to the different quantity of sequences, localities and genes used, than the possible different histories of each taxon. Populations from the Parnaíba and Mearim basins showed high indices of haplotype diversity (h) for both species, and Itapecuru and Tocantins basins also presented high levels of haplotype diversity in $P$. lacustris. All populations showed low levels of nucleotide diversity ( $\pi$ ) (Tab. 2). The neutrality indices of Tajima' D and Fu' Fs were not significant for populations of $S$. dissimilis ( $\mathrm{p}>0.05$ ), confirming the hypothesis of neutrality, and although significant among populations of P. lacustris ( $\mathrm{p}<0.001)$ from the Parnaíba and Mearim basins (Tab. 2 ), not enough to deny the hypothesis of selective neutrality once the stability can only be rejected if both analyses are significant for all populations. Populations of $S$. dissimilis from the Itapecuru basin showed only one haplotype, which was not enough to make inferences of any indices.

The SAMOVA test separated the studied populations of $S$. dissimilis in three groups (Fig. 2A) and P. lacustris in six groups (Fig. 3A), most of the molecular variance is

TABLE 2 । Genetic diversity indices and neutrality test for samples of Schizodon dissimilis and Prochilodus lacustris analyzed in this study. $\mathrm{h}=$ haplotype diversity; $\pi$ = nucleotide diversity; $D=$ Tajima test; Fs = Fu test; $\mathrm{p}=$ significance probability. $\mathrm{p}$ for Fs = 0.02 .

\begin{tabular}{|c|c|c|c|c|c|c|c|c|c|}
\hline \multirow{2}{*}{ Species } & \multirow{2}{*}{ Basin } & \multirow{2}{*}{$\begin{array}{l}\text { Sample } \\
\text { size }\end{array}$} & \multirow{2}{*}{$\begin{array}{l}\text { Haplotype } \\
\text { number }\end{array}$} & \multicolumn{2}{|c|}{ Diversity indices } & \multicolumn{4}{|c|}{ Neutrality tests } \\
\hline & & & & $\mathbf{h}$ & $\pi$ & D & $\mathbf{p}$ & Fs & $\mathbf{p}$ \\
\hline \multirow{4}{*}{$\begin{array}{l}\text { Schizodon } \\
\text { dissimilis }\end{array}$} & Parnaíba & 21 & 6 & 0.638 & 0.003 & -0.477 & 0.350 & -0.321 & 0.438 \\
\hline & Itapecuru & 13 & 1 & 0.000 & 0.000 & 0.000 & 1.000 & - & - \\
\hline & Mearim & 29 & 9 & 0.798 & 0.022 & 2.124 & 0.993 & 6.999 & 0.987 \\
\hline & Turiaçu & 7 & 2 & 0.286 & 0.001 & -1.006 & 0.239 & -0.095 & 0.209 \\
\hline \multirow{5}{*}{$\begin{array}{c}\text { Prochilodus } \\
\text { lacustris }\end{array}$} & Parnaíba & 21 & 19 & 0.990 & 0.011 & -0.548 & 0.210 & -10.229 & 0.000 \\
\hline & Itapecuru & 21 & 7 & 0.819 & 0.008 & 0.098 & 0.600 & 2.109 & 0.780 \\
\hline & Mearim & 42 & 19 & 0.904 & 0.006 & -0.677 & 0.290 & -6.914 & 0.000 \\
\hline & Turiaçu & 10 & 4 & 0.533 & 0.007 & -0.127 & 0.520 & 3.087 & 0.900 \\
\hline & Tocantins & 7 & 6 & 0.952 & 0.015 & 1.059 & 0.870 & 0.263 & 0.420 \\
\hline
\end{tabular}


explained by differences among groups of populations in both species with a percentage of total variance of $96.33 \%\left(\mathrm{~F}_{\mathrm{CT}}=0.963 ; \mathrm{p}=0.00\right)$ in S. dissimilis and $60.29 \%\left(\mathrm{~F}_{\mathrm{CT}}=\right.$ 0.603; $\mathrm{p}<0.001)$ in P. lacustris. The fixation indices are significant at all spatial scales supporting spatially structured populations in the groups (Tab. 3).

The BAPS analysis identified the same number of groups as did SAMOVA for $S$. dissimilis $(\log (\mathrm{ml})=-280.2301$; Fig. $2 \mathrm{~B})$ and P. lacustris $(\log (\mathrm{ml})=-881.0328$; Fig. 3B $)$, as well as the haplotype networks (Figs. $2 \mathrm{C}$ and $3 \mathrm{C}$ ). For $S$. dissimilis three groups were identified (the colors in parentheses correspond to Fig. 2A, C): the first group is formed by specimens from Parnaíba and Mearim drainages (green), the second by specimens from Parnaíba, Itapecuru, and Mearim drainages (blue), and the third formed by specimens from Turiaçu and Mearim drainages (red). The large number of mutational steps observed in the network indicate the strong genetic structure and a potential putative new species in the Turiaçu and Mearim drainages. For P. lacustris, six groups were identified with specimens from the drainages (the colors in parentheses correspond to Fig. 3A, C): 1) Parnaíba and Mearim (blue), 2) Parnaíba and Itapecuru (yellow), 3) Turiaçu and Tocantins (aqua), 4) Itapecuru, Turiaçu, and Tocantins (pink), 5) Parnaíba, Itapecuru, and Mearim (green) and 6) Parnaíba, Itapecuru, Mearim, and Tocantins (red). The paleodrainage reconstruction recover four paleodrainages for the studied area, which S. dissimilis is present in three paleodrainages and P. lacustris in four. It is necessary highlight that our reconstruction possesses a different configuration those presented by Thomaz, Knowles (2018), that identified six paleodrainages for part of the studied area.

The results of AMOVA analysis (Tab. 4) for $S$. dissimilis identified that all results, except to paleobasins, showed that the principal variance are among populations within groups. For P. lacustris all results, except to paleobasins showed that the principal variance is within populations. These results indicate that none of these geological scenario supports the observed genetic structure, which is an indicative that the principal events responsible for the differentiation in these species are the river capture and dispersal probably by paleodrainage to contribute for the occupation of the region. The comparison of Fst values (Tab. 5) was high only between Itapecuru and Turiaçu for S. dissimilis, and Parnaíba and Mearim for P. lacustris.

The time-calibrated phylogeny indicated that populations of $S$. dissimilis diverged about 600,000 years (Fig. 4), when the group inhabiting the Turiaçu and Mearim basins

TABLE 3 I Molecular variation by SAMOVA for samples of Schizodon dissimilis and Prochilodus lacustris analyzed in this study.

\begin{tabular}{|c|c|c|c|c|c|}
\hline Species & Variance component & Variance & $\begin{array}{c}\text { Variance } \\
\text { percentage }\end{array}$ & F-statistics & $\mathbf{p}$ \\
\hline \multirow{2}{*}{$\begin{array}{c}\text { Schizodon } \\
\text { dissimilis }\end{array}$} & $\begin{array}{c}\text { Among groups } \\
\text { Among populations }\end{array}$ & 9.530 & 96.330 & $\mathrm{~F}_{\mathrm{CT}}=0.963$ & 0.000 \\
& $\begin{array}{c}\text { within groups } \\
\text { Within populations }\end{array}$ & 0.060 & 0.600 & $\mathrm{~F}_{\mathrm{SC}}=0.163$ & 0.000 \\
\hline \multirow{2}{*}{$\begin{array}{c}\text { Amochilodus groups } \\
\text { lacustris }\end{array}$} & $\begin{array}{c}\text { Among populations } \\
\text { within groups }\end{array}$ & 0.950 & 3.070 & $\mathrm{~F}_{\mathrm{ST}}=0.969$ & 0.027 \\
& Within populations & 4.570 & 39.630 & $\mathrm{~F}_{\mathrm{ST}}=0.604$ & 0.000 \\
\hline
\end{tabular}



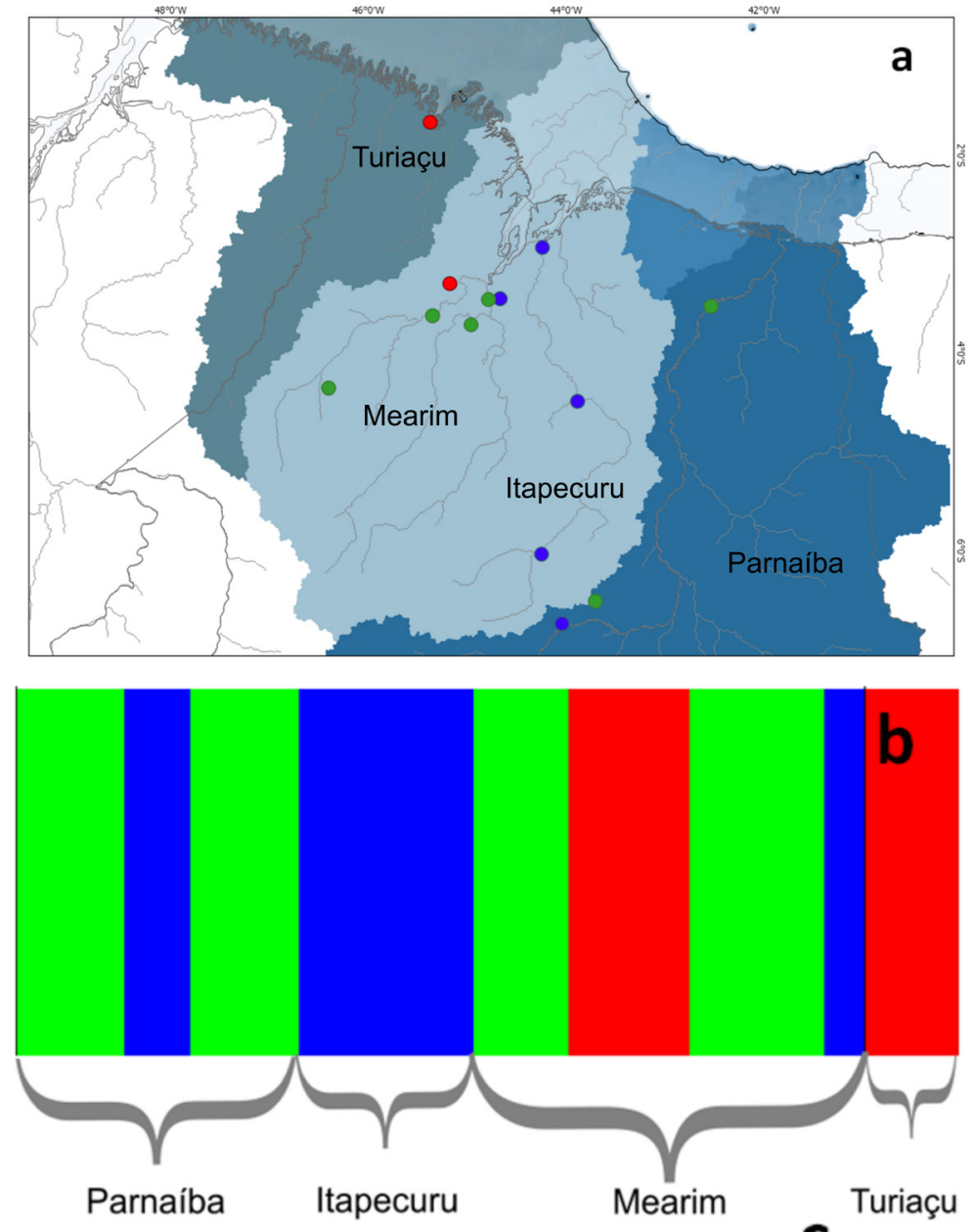

Parnaíba Itapecuru

C

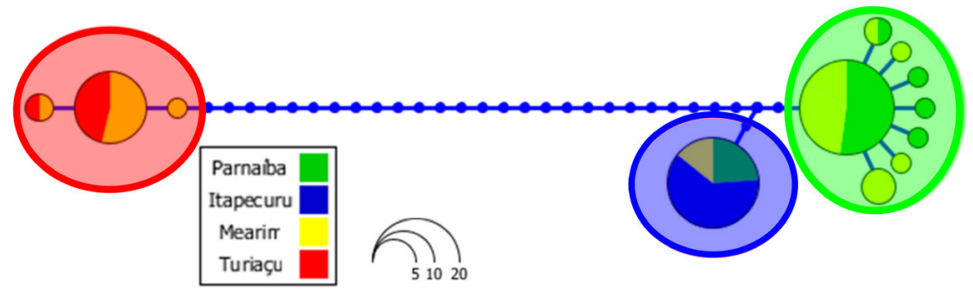

FIGURE 2 I Distribution and haplotype structure of Schizodon dissimilis. A. Paleodrainage reconstruction of coastal basins from northeastern Brazil and geographic distribution of groups defined by SAMOVA. B. Estimate of the probable groups of populations produced by the BAPS. C. Haplotypes network of cytochrome oxidase I ( $c o I)$. All analysis recovered a total of three groups in this area. The colors used to highlight areas in the network correspond to populations in map.

separated from the other groups. The P. lacustris populations have divergence times, closer to 600,000 years (Fig. 5) when most individuals from Parnaíba and Tocantins became separated from the other groups. 

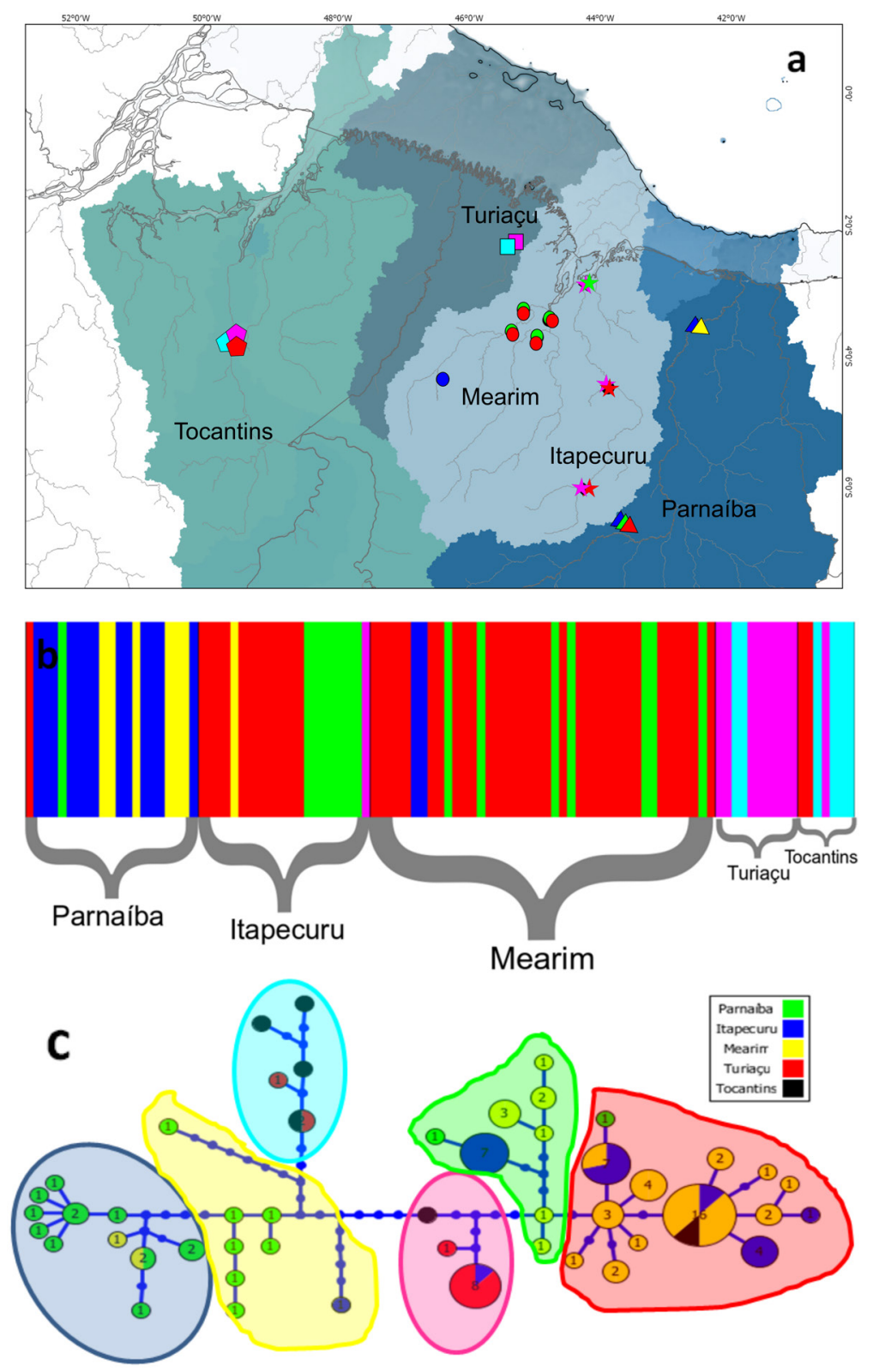

FIGURE 3 I Distribution and haplotype structure of Prochilodus lacustris. A. Paleodrainage reconstruction of coastal basins from northeastern Brazil and geographic distribution of groups defined by SAMOVA. B. Estimate of the probable groups of populations produced by the BAPS. C. Haplotypes networks of mtDNA control region. All analysis recovered a total of six groups in this area, but the SAMOVA do not identify the same groups that other analysis. The colors used to highlight areas in the network correspond to populations in map.

\section{DISCUSSION}

The relationships obtained among populations of $S$. dissimilis and P. lacustris may be associated with at least two important biogeographic events in this region: 1) headwater 
TABLE 4 I Molecular variation by AMOVA for samples of Schizodon dissimilis and Prochilodus lacustris analyzed in this study.

\begin{tabular}{|c|c|c|c|c|c|}
\hline Species & Configuration & Among Groups & $\begin{array}{c}\text { Variation } \\
\text { Among Populations } \\
\text { Within Groups }\end{array}$ & Within Populations & Fst \\
\hline \multirow{4}{*}{ Schizodon dissimilis } & Ecoregions (K=2) & -36.18 & 84.23 & 51.96 & 0.480 \\
\hline & Endemism areas $(\mathrm{K}=2)$ & -36.18 & 84.23 & 51.96 & 0.480 \\
\hline & Paleobasins $(\mathrm{K}=3)$ & 26.56 & 30.65 & 42.79 & 0.572 \\
\hline & Current basins $(\mathrm{K}=4)$ & 30.97 & 64.76 & 4.26 & 0.957 \\
\hline \multirow{4}{*}{ Prochilodus lacustris } & Ecoregions $(\mathrm{K}=2)$ & 35.25 & 20.97 & 43.78 & 0.562 \\
\hline & Endemism areas $(\mathrm{K}=3)$ & 35.05 & 18.49 & 46.46 & 0.535 \\
\hline & Paleobasins $(\mathrm{K}=4)$ & 48.87 & 3.22 & 47.91 & 0.521 \\
\hline & Current basins $(\mathrm{K}=5)$ & 42.16 & 7.95 & 49.89 & 0.501 \\
\hline
\end{tabular}

TABLE 5 I Pairwise Fst values for samples of Schizodon dissimilis and Prochilodus lacustris analyzed in this study.

\begin{tabular}{|c|c|c|c|c|c|}
\hline Species & Basin & Parnaíba & Itapecuru & Mearim & Turiaçu \\
\hline \multirow{4}{*}{$\begin{array}{l}\text { Schizodon } \\
\text { dissimilis }\end{array}$} & Parnaíba & & & & \\
\hline & Itapecuru & 0.521 & & & \\
\hline & Mearim & 0.049 & 0.462 & & \\
\hline & Turiaçu & 0.483 & 0.901 & 0.235 & \\
\hline \multirow{5}{*}{$\begin{array}{l}\text { Prochilodus } \\
\text { lacustris }\end{array}$} & Parnaíba & & & & \\
\hline & Itapecuru & 0.545 & & & \\
\hline & Mearim & 0.601 & 0.085 & & \\
\hline & Turiaçu & 0.432 & 0.463 & 0.541 & \\
\hline & Tocantins & 0.300 & 0.390 & 0.464 & 0.253 \\
\hline
\end{tabular}

captures between the Turiaçu-Mearim and Itapecuru-Parnaíba basins, presumed to have been caused by reactivation of several faults and lineaments (Costa et al., 1997; Soares Júnior et al., 2011), and 2) coastal dispersal (dispersal by paleodrainages) due Pleistocene sea level fluctuations and reticulated patterns of connectivity among the mouths of rivers on the coastal plain that repeatedly changed the basins configuration (Soares Júnior et al., 2011; Thomaz et al., 2017). Furthermore, different genetic markers identified similar events over the past 1.0 My influencing the geographic distribution of species and genetic differentiation of populations.

Shared haplotypes among $S$. dissimilis populations from Turiaçu and Mearim basins possibly occurred due to partial capture of Turiaçu by Mearim basin through damming and formation of lakes. The convergence of the Mearim, Pindaré and Grajaú rivers, influenced by quaternary neotectonic structures (Costa et al., 1997) and associated with transgressive and regressive sea movements (Soares Júnior et al., 2011), produced a set of interconnected lakes known as Baixada Maranhense. This is a wide plain region extending from the Mearim River to northwest in the direction of the Turiaçu valley. During the Lower Pleistocene (2.6 Ma $-0.1 \mathrm{Ma})$, the western edge of the region seems 


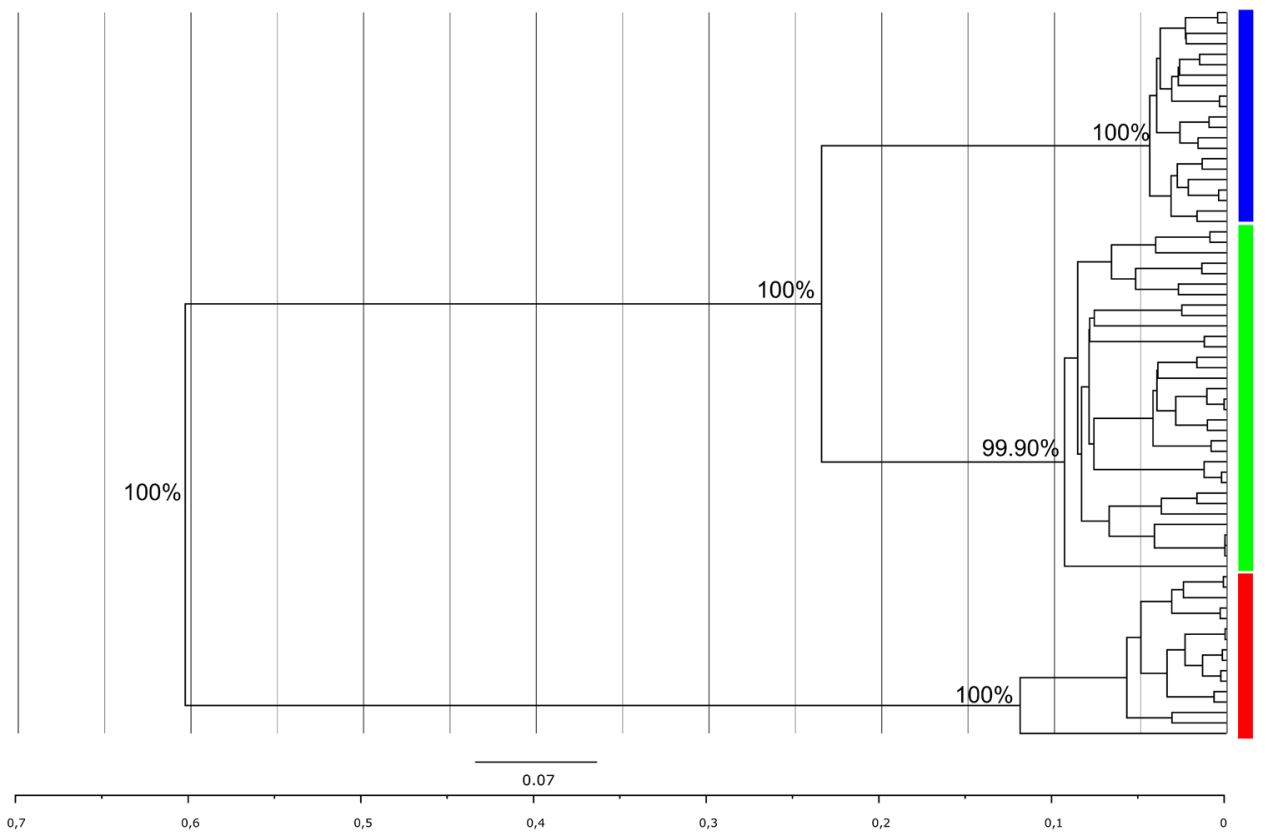

FIGURE 4 I Time-calibrated phylogeny for samples of Schizodon dissimilis from coastal basins of northeastern Brazil. Time is in thousands of years. The color bars in the tree correspond to the populations presented in Fig. 2A.

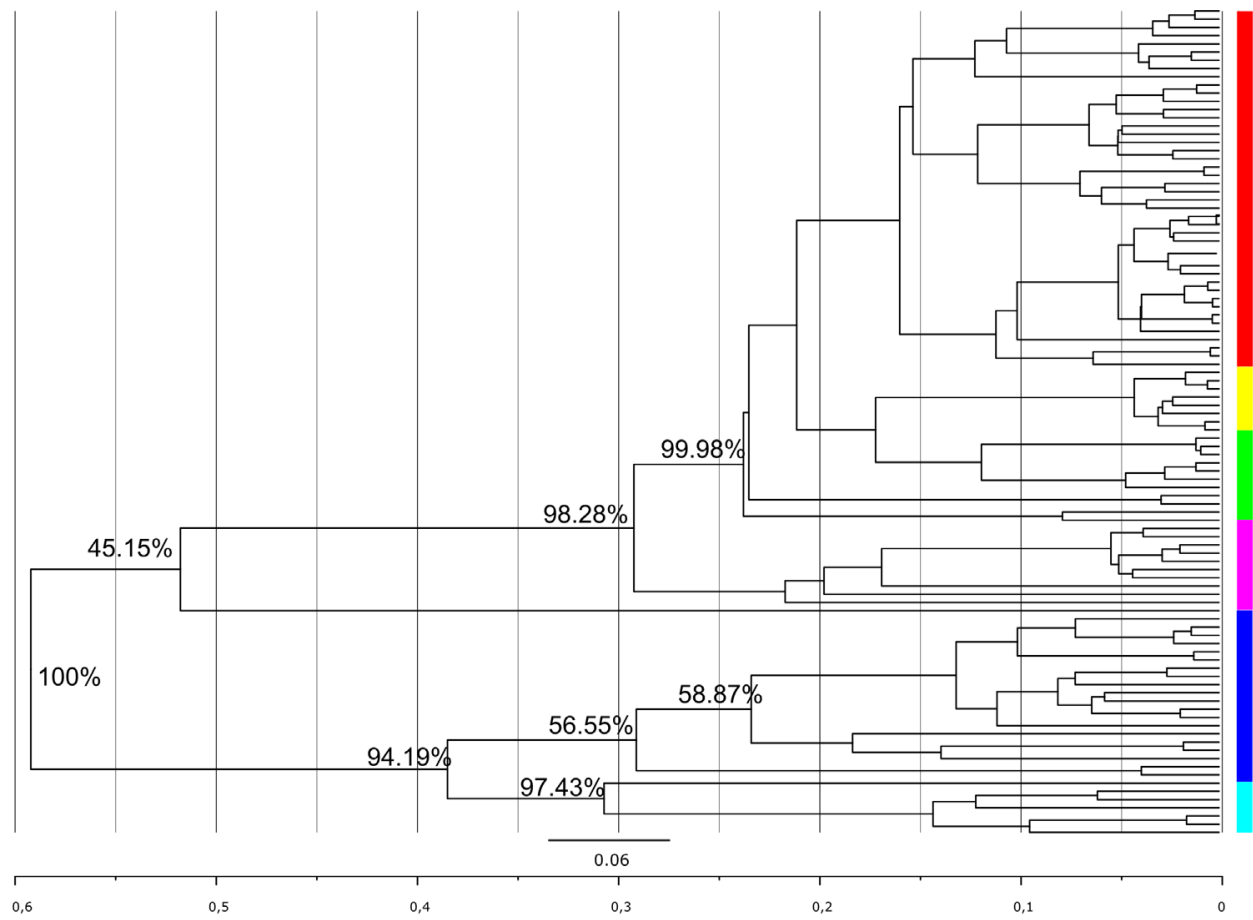

FIGURE 5 | Time-calibrated phylogeny for samples of Prochilodus lacustris from Maranhão coastal basins and Tocantins basin. Time is in thousands of years. The color bars in the tree correspond to the populations presented in Fig. 3A. 
to have been affected by a positive epeirogenesis resulting from tectonic reactivations of faults forming the Ferrer-Urbano Santos Arch, especially in the area of the remains of Gurupi belt (Klein et al., 2005). The Gurupi belt lies to the west of the Turiaçu River. Thus, its reactivation may have contributed to direct parts of the middle Turiaçu draining towards the Pindaré-Mearim system.

At that time, Pleistocene eustatic sea-level changes responsible for marine regressions and transgressions (Petri, Fúlfaro, 1983; Soares Júnior et al., 2011) may have controlled the connections between Turiaçu River and Pindaré-Mearim systems. These connections may have been favored during transgressive movements, when river flows were dammed and scattered across the interfluvium. This is plausible because there is some evidence floodplains promote connectivity between hydrological units and allow high levels of gene flow for species adapted to explore them (Balcombe et al., 2007), which is the case of these two rivers, whereas rivers with deep valleys will rarely overflow, leading populations to isolation and subsequent divergence (Burridge et al., 2007). Like many fish species that inhabit these regions, both investigated species have migratory habits and are commercially exploited (Godoy, 1975; Goulding, 1981), which facilitate dispersal processes. The low diversity identified in some populations could be an indicative that these populations are in constant contact by dispersal or could indicate a sample problem, once at least in Turiaçu all sample were collected just in one place. Another factor that could contribute to this lower diversity levels is the mixture among populations caused by the overflow of breeding tanks and release in the river of individuals from other locations.

The haplotype sharing, principally in S. dissimilis, between the Itapecuru and Parnaíba basins, can be explained by headwater capture events, probably occurred in the region between the modern cities of Nova Iorque and São João dos Patos, both in Maranhão state. These rivers have an elbow form which is characteristic of capture events (Rosa, 2004) that could be explained by the several reactivation processes of the Picos-Santa Inês Lineament, from its formation to the present, which was responsible for the change of direction of the middle and lower courses of these rivers (Cunha, 1986).

The results indicate relatively young divergence times for these species, which was not sufficient to allow visual identification of the new species. For example, although $S$. dissimilis populations exhibit substantial genetic divergence, they do not show clear morphological or morphometric differences (Abreu, 2013). The morphometric analysis developed by Abreu (2013) showed a strong overlap in the populations, that was not enough to separate in different species. Here we found a high number of mutational steps among the groups identified, suggesting the presence of cryptic species only detectable by genetic analyses and we suggest a review in morphological analysis for this specie.

Many studies of fish species distributions in the coastal basins of Brazil use paleodrainage reconstructions during the LGM at ca. $18-21 \mathrm{Ky}$ to explain the occurrence of species shared for the hydrographic basins (e.g. Thomaz et al., 2015, 2017; Lima et al., 2017; Tschá et al., 2017). In our reconstruction, the Mearim and Itapecuru basins belong to the same paleodrainage at the LGM, possibly explaining the shared haplotypes of populations of these basins, or perhaps demonstrating that modern watershed barriers are insufficient to block gene flow once the geographic distance does not strongly hinder dispersal in freshwater fishes of this region, as showed by Abreu et al. (2019). 
The probable dispersal of $S$. dissimilis and P. lacustris along the coastal plain of this area during the cyclic events of sea-level change, would have allowed shared haplotypes among these several basins that do not have hydrological connections today. Soares Júnior et al. (2011) proposed that in the end of Pleistocene the coast of Maranhão began to assume its current configuration, influenced directly by the sea-level fluctuations. Successive events of sea-level variation may have allowed species dispersal process in the region among the drainages and the subsequent isolation of populations in different basins.

The role of Pleistocene eustatic sea-level falls merging river mouths has long been understood to facilitate geographic range expansions of fish species along flat coastal plains (e.g. Huber, 1998; Albert et al., 2006; Dias et al., 2014; Thomaz et al., 2015). Likewise, the role of eustatic sea-level rises separating river mouths has been argued to isolate species in different river basins (e.g. Lundberg et al., 1998; Albert et al., 2006; López-Fernández, Albert, 2011). In combination, these marine regressions and transgression may be hypothesized to have had multiplicative effects over multiple cycles of merging and separating fish populations through Pleistocene, resulting in repeated rounds of dispersal, isolation, speciation, and extinction. The effects of climatic oscillations driving high species richness have been referred to as a "species pump" or "flickering connectivity system" hypothesis (e.g. Rossiter, 1995; Sedano, Burns, 2010; Papadopoulou, Knowles, 2015; Ferreira et al., 2017; Flantua, Hooghiemstra, 2018).

\section{ACKNOWLEDGMENTS}

This work was supported by grants from the US National Science Foundation DEB 0614334, 0741450 and 1354511 to J.S.A.; and from FAPEMA 011644/2016 to J.M.S.A., and FAPEMA 01490/16 to N.M.P.

\section{REFERENCES}

\section{- Abell R, Thieme ML, Revenga C, Bryer M, Kottelat M, Bogutskaya N et al.} Freshwater ecoregions of the world: A new map of biogeographic units for freshwater biodiversity conservation. BioScience. 2008; 58(5):403-14. https://doi.org/10.1641/ B580507

- Abreu JMS. Variação geográfica em Schizodon dissimilis (Garman, 1890) e diversidade genética e filogeográfica do grupo Schizodon fasciatus sensu lato (Characiformes: Anostomidae). [Master Dissertation]. Belém: Universidade Federal do Pará; 2013.

- Abreu JMS, Craig JM, Albert JS, Piorski NM. Historical biogeography of fishes from coastal basins of Maranhão State, northeastern Brazil. Neotrop Ichthyol. 2019; 17(2):e180156. https://doi. org/10.1590/1982-0224-20180156
- Albert JS, Carvalho TP, Petry P, Holder MA, Maxime EL, Espino J et al. Aquatic biodiversity in the amazon: Habitat specialization and geographic isolation promote species richness. Animals. 2011b; 1(2):205-41. https://doi.org/10.3390/ ani1020205

- Albert JS, Craig JM, Tagliacollo VA, Petry P. Upland and lowland fishes: A test of the River Capture Hypothesis. In: Hoorn C, Perrigo A, Antonelli A, editors. Mountains, Climate and Biodiversity. Chichester: Wiley Blackwell; 2018. p.273-94.

- Albert JS, Crampton WGR. The geography and ecology of diversification in Neotropical freshwaters. Nat Edu Know. 2010; 1:13-19. 
- Albert JS, Lovejoy NR, Crampton WGR. Miocene tectonism and the separation of cis-and trans-Andean river basins: Evidence from Neotropical fishes. J South Am Earth Sci. 2006; 21(1-2):14-27. https:// doi.org/10.1016/j.jsames.2005.07.010

- Albert JS, Petry P, Reis RE. Major biogeographic and phylogenetic patterns In: Albert JS, Reis RE, editors. Historical Biogeography of Neotropical Freshwater Fishes. Berkeley: University of California Press; 2011a. p.21-56.

- Albert JS, Schoolmaster DR, Jr., Tagliacollo V, Duke-Sylvester SM. Barrier displacement on a neutral landscape: toward a theory of continental biogeography. Syst Biol. 2016; 66(2):167-82. https://doi.org/10.1093/sysbio/syw080

- Balcombe SR, Bunn SE, Arthington AH, Fawcett JH, Mckenzie-Smith FJ, Wright A. Fish larvae, growth and biomass relationships in an Australian arid zone river: links between floodplains and waterholes. Freshwater Biol. 2007; 52(12):2385-98. https://doi.org/10.1111/ j.1365-2427.2007.01855.x

- Barros MC, Fraga EC, Birindelli JLO. Fishes from Itapecuru River basin, State of Maranhão, northeast Brazil. Braz J Biol. 2011; 71(2):375-80. https://doi.org/10.1590/ S1519-69842011000300006

- Beheregaray LB, Sunnucks P, Briscoe DA. A rapid fish radiation associated with the last sea-level changes in southern Brazil: the silverside Odontesthes perugiae complex. Proc R Soc Lond B Biol Sci. 2002; 269(1486):65-73. https://doi.org/10.1098/ rspb.2001.1838

- Bouckaert R, Heled J, Kühnert D, Vaughan T, Wu CH, Xie D et al. BEAST 2: A Software Platform for Bayesian Evolutionary Analysis. PLoS Comput Biol. 2014; 10(4):e1003537. https://doi. org/10.1371/journal.pcbi.1003537

- Burridge CP, Craw D, Waters JM. An empirical test of freshwater vicariance via river capture. Mol Ecol. 2007; 16(9):188395. https://doi.org/10.1111/j.1365294X.2006.03196.X

- Corander J, Cheng L, Marttinen P, Sirén J, Tang J. BAPS: Bayesian Analysis of Population Structure. Manual version 6.0. Finland: University of Helsinki; 2013.
- Costa JBS, Bemerguy RL, Hasui Y, Borges MS, Ferreira CRP, Jr., Bezerra PEL et al. Neotectônica da região amazônica: aspectos tectônicos, geomorfológicos e deposicionais. Geonomos. 1997; 4:23-44. https://doi.org/10.18285/geonomos.v4i2.199

- Cunha FMB. Evolução paleozóica da Bacia do Parnaíba e seu arcabouço tectônico. [Master Dissertation]. Rio de Janeiro: Instituto de Geociências; 1986.

- Darriba D, Taboada GL, Doallo R, Posada D. jModelTest 2: more models, new heuristics and parallel computing. Nat Methods. 2012; 9(8):772. https://doi. org/10.1038/nmeth.2109

- Dias MS, Oberdorff T, Hugueny B, Leprieur F, Jézéquel C, Cornu JF et al. Global imprint of historical connectivity on freshwater fish biodiversity. Ecol Lett. 2014; 17(9):1130-40. https://doi.org/10.1111/ ele.12319

- Dupanloup I, Schneider S, Excoffier L. A simulated annealing approach to define the genetic structure of populations. Mol Ecol. 2002; 11(12):2571-81. https://doi. org/10.1046/j.1365-294X.2002.01650.x

- Endler JA. Pleistocene forest refuges: fact or fancy? In: Prance GT, editor. Biological Diversification in the Tropics. New York: Columbia University Press; 1982. p.641-57.

- Excoffier L, Lischer HEL. Arlequin suite ver 3.5: A new series of programs to perform population genetics analysis under Linux and Windows. Mol Ecol Resour. 2010; 10(3):564-67. https://doi. org/10.1111/j.1755-0998.2010.02847.x

- Fagan WF. Connectivity, fragmentation, and extinction risk in dendritic metapopulations. Ecology. 2002; 83(12):3243-49. https://doi. org/10.1890/0012-9658(2002)083[3243:CFA ERI]2.0.CO;2

- Farias IP, Hrbek T. Patterns of diversification in the discus fishes (Symphysodon spp. Cichlidae) of the Amazon basin. Mol Phylogenet Evol. 2008; 49(1):32-43. https://doi.org/10.1016/j. ympev.2008.05.033

- Ferreira M, Aleixo A, Ribas CC, Santos MPD. Biogeography of the Neotropical genus Malacoptila (Aves: Bucconidae): the influence of the Andean orogeny, Amazonian drainage evolution and palaeoclimate. J Biogeogr. 2017; 44(4):74859. https://doi.org/10.1111/jbi.12888 
- Fjeldså J. Geographical patterns for relict and young species of birds in Africa and South America and implications for conservation priorities. Biodivers Conserv. 1994; 3:207-26.

- Flantua SGA, Hooghiemstra H. Historical Connectivity and Mountain Biodiversity. In: Hoorn C, Perrigo A, Antonelli A, editors. Mountains, Climate and Biodiversity. Chichester: Wiley Blackwell; 2018. p.171-86.

- Fricke R, Eschmeyer WN, Van der Laan R. Eschmeyer's catalog of fishes: genera, species, references [Internet]. San Francisco: California Academy of Science; 2020. Available from: http:// researcharchive.calacademy.org/ research/ichthyology/catalog/fishcatmain. asp

- Fu YX. Statistical tests of neutrality of mutations against population growth, hitchhiking and background selection. Genetics. 1997; 147:915-25.

- Garman S. On the species of the genus Anostomus. Bull Essex Inst. 1890; 22(13):15-23.

- Godoy MP. Peixes do Brasil: Subordem Characoide: Bacia do rio Mogi-Guassu. Piracicaba: Editora Franciscana; 1975.

- Goulding M. Man and fisheries on an Amazonian frontier. The Hague: Dr. W. Junk Publishers; 1981.

- Guimarães EC, Brito PS, Feitosa LM, Costa LFC, Ottoni FP. A new species of Hyphessobrycon Durbin from northeastern Brazil: evidence from morphological data and DNA barcoding (Characiformes, Characidae). Zookeys. 2018a; 765:79-101. https://dx.doi. org/10.3897\%2Fzookeys.765.23157

- Guimarães EC, Brito PS, Ferreira BRA, Ottoni FP. A new species of Charax (Ostariophysi, Characiformes, Characidae) from northeastern Brazil. Zoosyst Evol. 2018b; 94(1):83-93. https://doi.org/10.3897/ zse.94.22106

- Haffer J. Hypotheses to explain the origin of species in Amazonia. Braz J Biol. 2008; 68(4):917-47. https://doi.org/10.1590/ S1519-69842008000500003

- Hall TA. BioEdit: a user-friendly biological sequence alignment editor and analysis program for Windows 95/98/NT. Nucleic Acids Symp Ser. 1999; 41:95-98.
- Hanebuth TJJ, Voris HK, Yokoyama Y, Saito Y, Okuno JI. Formation and fate of sedimentary depocentres on Southeast Asia's Sunda Shelf over the past sea-level cycle and biogeographic implications. Earth-Sci Rev. 2011; 104(1-3):92-110. https://doi.org/10.1016/j. earscirev.2010.09.006

- Hansen J, Sato M, Russell G, Kharecha P. Climate sensitivity, sea level and atmospheric carbon dioxide. Philos Trans A Math Phys Eng Sci. 2013; 371(2001):20120294. https://doi. org/10.1098/rsta.2012.0294

- Huber JH. Comparison of old world and new world tropical Cyprinodonts. Paris: Société Française d'Ichtyologie; 1998.

- Hubert N, Renno JF. Historical biogeography of South American freshwater fishes. J Biogeogr. 2006; 33(8):1414-36. https://doi.org/10.1111/ j.1365-2699.2006.01518.x

- Klein EL, Moura CAV, Krymsky RS, Griffin WL. The Gurupi Belt, northern Brazil: Lithostratigraphy, geochronology, and geodynamic evolution. Precambrian Res. 2005; 141(3-4):83-105. https://doi. org/10.1016/j.precamres.2005.08.003

- Kocher D, Thomas WK, Meyer A, Edwards SV, Pääbo S, Villablanca FX, Wilson AC. Dynamics of mitochondrial DNA evolution in animals: amplification and sequencing with conserved primers. Proc Natl Acad Sci U S A. 1989; 86(16):6196-200. https://doi.org/10.1073/ pnas.86.16.6196

- Larkin MA, Blackshields G, Brown NP, Chenna R, McGettigan PA, McWilliam H et al. Clustal W and ClustalX version 2. Bioinformatics. 2007; 23(21):2947-48. https://doi.org/10.1093/bioinformatics/ btm404

- Lima SMQ, Berbel-Filho WM, Araújo TFP, Lazzarotto H, Tatarenkov A, Avise JC. Headwater capture evidenced by PaleoRivers reconstruction and population genetic structure of the armored catfish (Pareiorhaphis garbei) in the Serra do Mar Mountains of Southeastern Brazil. Front Genet. 2017; 8:199. https://doi.org/10.3389/ fgene.2017.00199

- López-Fernández H, Albert JS. Paleogene radiations. In: Albert JS, Reis RE, editors. Historical Biogeography of Neotropical Freshwater Fishes. Berkeley: University of California Press; 2011. p.105-17. 
- Lovejoy NR, Willis SC, Albert JS. Molecular signatures of Neogene biogeographical events in the Amazon fish fauna. In: Hoorn C, Wesselingh F, editors. Amazonia: Landscape and Species Evolution: A look into the past. Hoboken: Wiley-Blackwell; 2010. p.40517.

- Lundberg JG, Marshall LG, Guerrero J, Horton B, Malabarba MCSL, Wesselingh $\mathbf{F}$. The stage for neotropical fish diversification: a history of tropical South American rivers. In: Malabarba LR, Reis RE, Vari RP, Lucena ZM, Lucena CAS, editors. Phylogeny and classification of Neotropical fishes. Porto Alegre: Edipucrs; 1998. p.13-48

- Melo FAG, Buckup PA, Ramos TPA, Souza AKN, Silva CMA, Costa TC et al. Fish fauna of the lower course of the Parnaíba river, northeastern Brazil. Bol Mus Biol Mello Leitão. 2016; 38(4):363400.

- Montoya-Burgos JI. Historical biogeography of the catfish genus Hypostomus (Siluriformes: Loricariidae), with implications on the diversification of neotropical ichthyofauna. Mol Ecol. 2003; 12(7):1855-67. https://doi.org/10.1046/j.1365294X.2003.01857.x

- Ottoni FP. Cichlasoma zarskei, a new cichlid fish from northern Brazil (Teleostei: Labroidei: Cichlidae). Vertebr Zool. 2011; 61(3):335-42.

- Papadopoulou A, Knowles LL. Genomic tests of the species-pump hypothesis: recent island connectivity cycles drive population divergence but not speciation in Caribbean crickets across the Virgin Islands. Evolution. 2015; 69(6):1501-17. https://doi.org/10.1111/evo.12667

- Pereira LH, Hanner R, Foresti F, Oliveira C. Can DNA barcoding accurately discriminate megadiverse Neotropical freshwater fish fauna?. BMC Genet. 2013; 14(20):1-14. https://doi.org/10.1186/14712156-14-20

- Petri S, Fúlfaro VJ. Geologia do Brasil. São Paulo: Editora da Universidade de São Paulo (Edusp); 1983.

- Piorski NM. Diversidade genética e filogeografia das espécies Hoplias malabaricus (Bloch, 1794) e Prochilodus lacustris Steindachner, 1907 no Nordeste do Brasil. [PhD Thesis]. São Carlos: Universidade Federal de São Carlos; 2010.
- Piorski NM, Castro ACL, Pereira LG, Muniz MEL. Ictiofauna do trecho inferior do rio Itapecuru, Nordeste do Brasil. Bol Lab Hidrobiol. 1998; 11(1):15-24.

- Piorski NM, Castro ACL, Pinheiro CUB. A prática da pesca entre os grupos indígenas das bacias dos rios Pindaré e Turiaçu, no Estado do Maranhão, Nordeste do Brasil. Bol Lab Hidrobiol. 2003; 16(1):67-74.

- Piorski NM, Castro ACL, Sousa Neto AM. Peixes do cerrado da região sul maranhense. In: Barreto LN, editor. Cerrado Norte do Brasil. São Luís: USEB; 2007. p.177-212.

- Piorski NM, Garavello JC, Arce-H M, Sabaj-Pérez MH. Platydoras brachylecis, a new species of thorny catfish (Siluriformes: Doradidae) from Northeastern Brazil. Neotrop Ichthyol. 2008; 6(3):481-94. http://dx.doi.org/10.1590/ S1679-62252008000300021

- QGIS Development Team. QGIS Geographic Information System. Open Source Geospatial Foundation Project; 2018. Available from: http://qgis.osgeo.org

- Ramos TPA, Lima SMQ, Ramos RTC. A new species of armored catfish Parotocinclus (Siluriformes: Loricariidae) from the rio Parnaíba basin, northeastern, Brazil. Neotrop Ichthyol. 2017; 15(2):e160153. http://dx.doi. org/10.1590/1982-0224-20160153

- Ramos TPA, Ramos RTC, Ramos SAQA. Ichthyofauna of the Parnaíba River basin, northeastern Brazil. Biota Neotrop. 2014; 14(1):e20130039. http://dx.doi.org/10.1590/ S1676-06020140039

- Rocha YGPC, Ramos TPA, Ramos RTC. Phenacorhamdia cabocla, a new heptapterid from the Parnaíba River basin, Northeastern Brazil (Siluriformes: Heptapteridae). Zootaxa. 2018; 4402(2):353-62. https://doi.org/10.11646/ zootaxa.4402.2.7

- Rosa R. Diversidade e conservação dos peixes da Caatinga. In: Silva JMC, Tabarelli M, Fonseca MT, Lins LV, editors. Biodiversidade da caatinga: áreas e ações prioritárias para a conservação. Brasília: Ministério do Meio Ambiente; 2004. p.149-61.

- Rossiter A. The cichlid fish assemblages of Lake Tanganyika: ecology, behavior and evolution of its species flocks. Adv Ecol Res. 1995; 26:187-252. https://doi. org/10.1016/S0065-2504(08)60066-5 
- Roxo FF, Albert JS, Silva GSC, Zawadzki CH, Foresti F, Oliveira C. Molecular phylogeny and biogeographic history of the armored Neotropical catfish subfamilies Hypoptopomatinae, Neoplecostominae and Otothyrinae (Siluriformes: Loricariidae). PLoS One. 2014; 9(8):e105564. https://doi.org/10.1371/ journal.pone.0105564

- Roy MS, Silva JMC, Arctander P, GarciaMoreno J, Fjeldså J. The speciation of South American and African birds in montane regions. In: Mindell DP, editor. Avian molecular evolution and systematics. San Diego: Academic Press; 1997. p.325-43.

- Salzburger W, Ewing GB, Von Haeseler A. The performance of phylogenetic algorithms in estimating haplotype genealogies with migration. Mol Ecol. 2011; 20(9):1952-63. https://doi.org/10.1111/ j.1365-294X.2011.05066.x

- Sedano RE, Burns KJ. Are the Northern Andes a species pump for Neotropical birds? Phylogenetics and biogeography of a clade of Neotropical tanagers (Aves: Thraupini). J Biogeogr. 2010; 37(2):325-43. https://doi.org/10.1111/j.13652699.2009.02200.x

- Sivasundar A, Bermingham E, Orti G. Population structure and biogeography of migratory freshwater fishes (Prochilodus: Characiformes) in major South American rivers. Mol Ecol. 2001; 10(2):407-17. https:// doi.org/10.1046/j.1365-294X.2001.01194.X

- Soares EC. Peixes do Mearim. São Luís: Instituto GEIA; 2005.

- Soares Júnior AV, Hasui Y, Costa JBS, Machado FB. Evolução do rifteamento e paleogeografia da margem atlântica equatorial do Brasil: Triássico ao Holoceno. Geociências. 2011; 30(4):669-92. Available from: http://hdl.handle.net/11449/72935

- Tajima F. Statistical method for testing the neutral mutation hypothesis by DNA polymorphism. Genetics. 1989; 123(3):58595.

- Thomaz AT, Knowles LL. Flowing into the unknown: inferred paleodrainages for studying the ichthyofauna of Brazilian coastal rivers. Neotrop Ichthyol. 2018; 16(3):e180019. http://dx.doi. org/10.1590/1982-0224-20180019
- Thomaz AT, Malabarba LR, Bonatto SL, Knowles LL. Testing the effect of palaeodrainages versus habitat stability on genetic divergence in riverine systems: study of a Neotropical fish of the Brazilian coastal Atlantic Forest. J Biogeogr. 2015; 42(12):2389-401. https://doi.org/10.1111/ jbi.12597

- Thomaz AT, Malabarba LR, Knowles LL. Genomic signatures of paleodrainages in a freshwater fish along the southeastern coast of Brazil: genetic structure reflects past riverine properties. Heredity. 2017; 119(4), 287-94. http://dx.doi.org/10.1038/ hdy.2017.46

- Tschá MK, Bachmann L, Abilhoa V, Boeger WA. Past connection and isolation of catchments: The sea-level changes affect the distribution and genetic variability of coastal freshwater fishes. Estuar Coast Shelf Sci. 2017; 190:31-39. https://doi. org/10.1016/j.ecss.2017.02.030

- Ward RD, Zemlak TS, Innes BH, Last PR, Hebert PDN. DNA barcoding Australia's fish species. Philos Trans R Soc Lond B Biol Sci. 2005; 360(1462):1847-57. https://doi. org/10.1098/rstb.2005.1716

- Weatherall P, Marks KM, Jakobsson M, Schmitt T, Tani S, Arndt JE et al. A new digital bathymetric model of the world's oceans. Earth Space Sci. 2015; 2(8):331-45. https://doi.org/10.1002/2015EA000107

- Winemiller KO, López-Fernández H, Taphorn DC, Nico LG, Duque AB. Fish assemblages of the Casiquiare River, a corridor and zoogeographical filter for dispersal between the Orinoco and Amazon basins. J Biogeogr. 2008; 35(9):1551-63. https://doi.org/10.1111/ j.1365-2699.2008.01917.x

- Zanata AM, Ramos TPA, OliveiraSilva L. A new species of Characidium (Characiformes: Crenuchidae) from the rio Parnaíba basin, northeastern Brazil. Zootaxa. 2018; 4514(1):77-86. https://doi. org/10.11646/zootaxa.4514.1.6 


\section{Neotropical |chthyology}

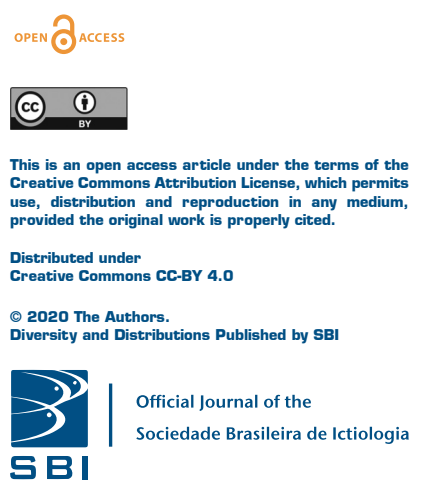

\section{AUTHOR'S CONTRIBUTION}

João Marcelo da Silva Abreu: Conceptualization, Formal analysis, Methodology, Writing-original draft, Writing-review \& editing.

Brandon T. Waltz: Conceptualization, Formal analysis, Methodology, Writing-original draft, Writingreview \& editing.

James S. Albert: Conceptualization, Formal analysis, Methodology, Writing-original draft, Writing-review \& editing.

Nivaldo Magalhães Piorski: Conceptualization, Data curation, Formal analysis, Methodology, Writingoriginal draft, Writing-review \& editing.

\section{ETHICAL STATEMENT}

This work was approved by the Ethical Committee for Animal Use in Experiments of the Universidade Federal do Maranhão (CEUA 23115.008137/2016-96).

\section{COMPETING INTERESTS}

The authors declare no competing interests.

HOW TO CITE THIS ARTICLE

- Abreu JMS, Waltz BT, Albert JS, Piorski NM. Genetic differentiation through dispersal and isolation in two freshwater fish species from coastal basins of Northeastern Brazil. Neotrop Ichthyol. 2020; 18(3):e190114. https://doi.org/10.1590/1982-0224-2019-0114 